\title{
Bio-Economics Of Feeding Cassava Root Meal Based Diets to Broiler Finisher
} \section{Chickens.}

\author{
${ }^{1}$ Nsa, E. E., ${ }^{2}$ Ukoha, O. A. and ${ }^{2}$ Agida, C. A. \\ ${ }^{\prime}$ Department of Animal Science, University of Calabar, Calabar. \\ ${ }^{2}$ Department of forage and Nutrition, Micheal Okpara, \\ University of Agriculture, Umudike.
}

Corresponding author:onyedinma26@gmail.com +2348063967602

\section{Abstract}

A study was conducted to investigate the bio-economics of feeding broiler chickens graded levels of cassava root meal based diets, as replacement for maize at 0, 25, 50, 75 and 100\% to form treatment diets $T_{1}, T_{2}, T_{3}, T_{4}$ and $T_{5,}$ respectively, with adjustment in soybean levels across the treatment diets to have iso-nitrogenous diets. Two hundred and forty- 4 weeks old 'Amos' strain broiler chicks were in a completely randomized design allotted randomly to five treatment groups of 48 birds each and of three replicates with each replicate having 16 birds. Parameters measured included weight gain, feed intake, feed gain ratio, price per kg offeed, price per $\mathrm{kg}$ of broiler and weight of carcass cuts. Data were analyzed using analysis of variances. Daily weight gain for $T_{1}, T_{2}, T_{3}, T_{4}$ and $T_{5}$ were $41.16 \mathrm{~g} / \mathrm{b} / \mathrm{d}, 39.43,33.47,25.25$ and $16.91 \mathrm{~g} / \mathrm{b} / \mathrm{d}$, respectively while, daily feed intake for $T_{1}, T_{2}, T_{3}, T_{4}$ and $T_{5}$ were $113.35 \mathrm{~g}, 112.75$, 102.31, 93.34 and 85.94g, respectively. Results showed weight gain feed intake and feed Conversion ratio values to be significantly $(P<0.05)$ depressed as the level of replacement of maize with cassava root meal exceeded 25\%. Among the carcass parameters, only the dressed carcass (\%) and thigh (\%) weight values showed significant $(P<0.05)$ decrease as the level of replacement level of maize with cassava root meal exceeded $25 \%$ while, spleen $(\%)$ and liver $(\%)$ values showed progressive increase $(P<0.05)$ in weight as the level of cassava root meal increased in the diets. Cost of feed decreased $(p<0.05)$ significantly with the increasing level of cassava root meal. However, it did not translate to increase in price per $\mathrm{kg}$ of bird. It could therefore be suggested that cassava root meal should not exceed $25 \%$ as replacement for maize in broiler finisher diets, as beyond this level growth performance is adversely impaired.

Keywords: cassava root meal, bio-economics, growth performance, iso-nitrogenous, broiler chicken

\section{Introduction}

Maize and wheat are major sources of energy in poultry and livestock feeds and can be used up to $60 \%$ in poultry diets. However, amongst other factors, industrial demands by ethanol and food producing industry have contributed greatly to the shortage in supply and exorbitant prices of these energy rich grains (Tyner and Taheripour, 2007), thus becoming uneconomical to use them in poultry feeds (Esonu and Udedibie, 2003). There is therefore, need to source for other feed materials, which are cost effective in feeding livestock (Munyaka et al., 20015). Such feed materials, as a matter of necessity must be readily and abundantly available in the given area of production (Nsa et al., 2016). One of such is cassava (Manihot esculenta). This crop can survive and produce good yield in a wide range of environmental and climatic conditions. It is abundant in tropical and sub-tropical areas including, Nigeria, Brazil and Thailand (Garcia and Dele, 1999). Cassava root meal, whole cassava meal, cassava leaf meal, cassava peel meal are the main cassava products used in poultry diets 


\section{Bio-Economics Of Feeding Cassava Root Meal Based Diets to Broiler Finisher Chickens}

(Borin et al., 2006: Obikaonu et al., 2006; Anaeto and Adighibe 2011, Adeyemi et al. 2008). According to Anaeto and Adighide (2011) and Nsa et al. (2016), the use of cassava as alternative to conventional energy feed stuff like maize could reduce the cost of livestock and poultry feeds. Cassava however, contains various levels of cyanogenic glycosides, mainly as linamarin and to a lesser extent as lotaustralin which are present in the leaf and root of the plant (Agbor-Egbe and Mbome, 2006). The low protein content, essential vitamin and minerals have been the major factors limiting its use in poultry diets. Although high in arginine, glutamic acid and aspartic acid, other amino acids such as methionine, cysteine, phenylalanine, threonine, proline and isoleucine in cassava are low relative to maize (Buitrago et al., 2002). The fiber content depends on the variety and the age of the root and is estimated at $4.4 \%$ for the sweet variety and $4.6 \%$ for the bitter variety compared to $1.3 \%$ and $2.7 \%$ reported for maize and wheat, respectively (Sarkiyayi, 2010; Nuss and Tanumihardjo, 2010). Anaeto and Adighibe (2011), pointed out that for cassava to be able to replace maize it must undergo good processing such as cooking, sun drying, roasting, ensiling and fermentation to reduce or eliminate the cyanogenic glycosides content. Other authors have advocated the use of some sources of proteins like soybean and Cray fish to fortify the cassava root meal in order to enrich the meal for successful usage as replacement for maize in both poultry and livestock feeds (Nsa et al., 2016). This study therefore was aimed at assessing the cost implications and growth response of broiler finisher birds fed graded levels of milled cassava root meal-based diets.

\section{Materials and methods Location of study}

The experiment was carried out at the poultry unit of the Department of Animal
Science Teaching and Research Farm, University of Calabar, Nigeria.

\section{Management of experimental birds}

Two hundred and forty (240), four weeks old birds were used for the experiments, they were randomly allotted to five treatments with three replicates of 16 birds each. Birds were tagged for easy identification and were raised in a deep litter pens. Experimental feeds and water were provided ad libitum. All vaccinations and medications programs were followed strictly.

\section{Processing of test ingredients}

Sweet cassava roots (Manihot esculanta) were peeled and processed into meals with the use of meadow model 35 hammer mill, squeezed and sieved through a mesh of 5 $\mathrm{mm}$. The meal was sundried by spreading them on concrete slab and allowed to dry for three days before been packed into jute bags.

\section{Experimental diets and design}

Data on feed intake were collected on daily basis, while live weight was measured weekly and used in calculating, weight gain, feed conversion ratio. The prevailing prices of ingredients at the time of experiments was used to calculate cost of $1 \mathrm{~kg}$ of feed consumed and priced of $1 \mathrm{~kg}$ of feed consumed/weight gained. All data were subjected to analysis of variance (ANOVA). The significant difference between treatments means were separated using Duncan's Multiple Range test of SAS (2012).

\section{Results}

The results of the growth performance of broiler finisher birds fed cassava root meal based diets is shown in Table 2. There were no significant $(\mathrm{P}>0.05)$ differences in all the growth parameters observed between chickens on control diet $\left(\mathrm{T}_{1}\right)$ and those on T2 (25\% replacement of maize with cassava leaf meal). But beyond $25 \%$ level of replacement, all of the growth parameters 
Nsa, Ukoha and Agida

Table 1: Gross composition of experimental broiler finisher diets

\begin{tabular}{|c|c|c|c|c|c|}
\hline Ingredients & $T_{1}$ & $\mathbf{T}_{2}$ & $\mathbf{T}_{3}$ & $\mathbf{T}_{4}$ & T5 \\
\hline Maize & 60.00 & 45.00 & 30.00 & 15.00 & 0.00 \\
\hline Cassava root meal(CRM) & 0.00 & 15.00 & 30.00 & 45.00 & 60.00 \\
\hline Soybean meal & 28.00 & 29.00 & 30.00 & 31.00 & 32.00 \\
\hline Fish meal & 2.40 & 2.40 & 2.40 & 2.40 & 2.40 \\
\hline Wheat offal & 6.00 & 4.50 & 3.00 & 1.50 & 0.00 \\
\hline $\mathrm{DCP}$ & 2.50 & 2.50 & 2.50 & 2.50 & 2.50 \\
\hline Salt & 0.35 & 0.35 & 0.35 & 0.35 & 0.35 \\
\hline Lysine & 0.25 & 0.25 & 0.25 & 0.25 & 0.25 \\
\hline Methionine & 0.25 & 0.25 & 0.25 & 0.25 & 0.25 \\
\hline *Vit./min. premix & 0.25 & 0.25 & 0.25 & 0.25 & 0.25 \\
\hline Total & 100.00 & 100.00 & 100.00 & 100.00 & 100.00 \\
\hline \multicolumn{6}{|l|}{ Calculated Analysis } \\
\hline Crude protein (\%) & 21.82 & 21.76 & 21.70 & 21.64 & 21.58 \\
\hline Crude fiber $(\%)$ & 4.88 & 4.84 & 4.80 & 4.76 & 4.72 \\
\hline $\mathrm{ME}(\mathrm{Kcal} / \mathrm{kg})$ & 3100.08 & 2993.41 & 298016 & 2966.00 & 2941.26 \\
\hline \multicolumn{6}{|l|}{ Determined Analysis } \\
\hline Crude Protein (\%) & 21.41 & 21.22 & 21.18 & 21.06 & 21.00 \\
\hline Crude fibre (\%) & 4.91 & 4.87 & 4.81 & 4.66 & 4.59 \\
\hline
\end{tabular}

*Composition per 2kgof mixture contains; Vitamin A - 15,000,000 iu, Vitamin D - 3,000,000 iu,, Vitamin E - 15,000 iu, Vitamin K- 2.5g, Vitamin $B_{1}-1 \mathrm{~g}$, Vitamin $B_{2}-10 \mathrm{~g}$, Vitamin $B_{12}-4 \mathrm{~g}$, Folic acid - 2g, Biotin - 0.1g, Niacin - 70g, BHT $-125 \mathrm{~g}$, Calcium-Pantotenic acid $-20 \mathrm{~g}$

DCP represents dicalcium phosphate

were significantly $(\mathrm{P}<0.5)$ depressed as the level of cassava meal increased in the diets. Among the carcass indices shown in Table 3 , the dressed weight, thigh, liver and spleen weights showed significant differences $(\mathrm{P}<0.05)$. The dressed weight and thigh decreased $(\mathrm{P}>0.05)$ beyond $25 \%$ replacement level of maize with cassava root meal in the diets. The liver and spleen increased $(\mathrm{P}<0.05)$ with increasing level of cassava root meal in the diets. The cost implication of cassava root meal in broiler diet is shown in Table 4. The feed cost $/ \mathrm{kg}$ feed values significantly $(\mathrm{P}<0.05)$ decreased as the level of cassava meal increased in the diets. However, feed cost/gain ratio showed a reverse trend as it tended to increase as the level of cassava root meal increased in the diet, except diet $\mathrm{T}_{5}$.

Table 2: Growth Performance of broiler finisher birds fed cassava root meal based diets

\begin{tabular}{lcccccc}
\hline PARAMETER & $\mathbf{T}_{\mathbf{1}}$ & $\mathbf{T}_{\mathbf{2}}$ & $\mathbf{T}_{\mathbf{3}}$ & $\mathbf{T}_{\mathbf{4}}$ & $\mathbf{T}_{\mathbf{5}}$ & $\mathbf{S E M}$ \\
\hline Initial weight $(\mathrm{g})$ & 421.60 & 429.00 & 430.51 & 427.71 & 429.90 & 9.00 \\
Final weight $(\mathrm{g})$ & $1862.10^{\mathrm{a}}$ & $1809.00^{\mathrm{a}}$ & $1602.11^{\mathrm{b}}$ & $1311.50^{\mathrm{c}}$ & $1021.11^{\mathrm{d}}$ & 6.36 \\
Total weight gain $(\mathrm{g})$ & $1440.50^{\mathrm{a}}$ & $1380^{\mathrm{a}}$ & $1171.60^{\mathrm{b}}$ & $883.79^{\mathrm{b}}$ & $591.81^{\mathrm{c}}$ & 3.20 \\
Daily weight gain $(\mathrm{g})$ & $41.16^{\mathrm{a}}$ & $39.43^{\mathrm{a}}$ & $33.47^{\mathrm{b}}$ & $25.25^{\mathrm{c}}$ & $16.91^{\mathrm{d}}$ & 1.01 \\
Total feed intake $(\mathrm{g})$ & $3967.18^{\mathrm{a}}$ & $3946.10^{\mathrm{a}}$ & $3581.02^{\mathrm{b}}$ & $3266.91^{\mathrm{c}}$ & $3008.05^{\mathrm{c}}$ & 4.59 \\
Daily feed intake $(\mathrm{g})$ & $113.35^{\mathrm{a}}$ & $112.75^{\mathrm{a}}$ & $102.31^{\mathrm{b}}$ & $93.34^{\mathrm{b}}$ & $85.94^{\mathrm{c}}$ & 1.88 \\
FCR & $2.75^{\mathrm{d}}$ & $2.86^{\mathrm{d}}$ & $3.06^{\mathrm{c}}$ & $3.70^{\mathrm{c}}$ & $5.08^{\mathrm{a}}$ & 0.08 \\
\hline
\end{tabular}

FCR represents feed conversion ratio. $a, b, c$, means on the same row having different superscripts are significantly different $(\mathrm{P}<0.05)$

\section{Discussion}

The poor performance of birds observed in Table 2 in terms of weight gain, final live weight and feed gain ratio implies that increase in cassava root meal as replacement for maize in the diet of broiler finisher birds beyond 25\% level results in poor utilization of the diets. This depression in growth parameters further confirms the results of Longe and Oluyemi (1977); 
Bio-Economics Of Feeding Cassava Root Meal Based Diets to Broiler Finisher Chickens

Table 3: Carcass characteristics of broiler finisher birds fed cassava root meal based diets

\begin{tabular}{lllllll}
\hline Parameter & $\mathbf{T}_{\mathbf{1}}$ & $\mathbf{T}_{\mathbf{2}}$ & $\mathbf{T}_{\mathbf{3}}$ & $\mathbf{T}_{\mathbf{4}}$ & $\mathbf{T}_{\mathbf{5}}$ & $\mathbf{S E M}$ \\
\hline Dressed carcass & $67.01^{\mathrm{a}}$ & $67.00^{\mathrm{a}}$ & $65.10^{\mathrm{b}}$ & $63.32^{\mathrm{c}}$ & $61.00^{\mathrm{d}}$ & 2.41 \\
Drumstick & 9.96 & 9.98 & 9.43 & 9.30 & 9.31 & 0.45 \\
Thigh & $12.41^{\mathrm{a}}$ & $12.38^{\mathrm{a}}$ & $11.43^{\mathrm{b}}$ & $11.00^{\mathrm{c}}$ & $10.93^{\mathrm{c}}$ & 0.39 \\
Wing & 8.82 & 8.79 & 8.50 & 8.32 & 8.00 & 0.16 \\
Breast muscle & 18.09 & 18.09 & 18.01 & 17.79 & 17.81 & 1.73 \\
Shank & 6.11 & 6.12 & 6.13 & 6.19 & 6.21 & 0.20 \\
Back & 13.12 & 13.09 & 13.04 & 13.0 & 13.06 & 1.29 \\
Gizzard & 3.86 & 3.90 & 4.10 & 4.16 & 4.33 & 0.27 \\
Heart & 0.62 & 0.73 & 0.76 & 0.77 & 0.81 & 0.01 \\
Liver & $4.02^{\mathrm{e}}$ & $4.36^{\mathrm{d}}$ & $4.58^{\mathrm{c}}$ & $4.79^{\mathrm{b}}$ & $4.88^{\mathrm{a}}$ & 0.11 \\
Lungs & 0.99 & 0.89 & 0.88 & 0.88 & 0.82 & 0.01 \\
Spleen & $0.33^{\mathrm{e}}$ & $0.41^{\mathrm{d}}$ & $0.49^{\mathrm{e}}$ & $0.53^{\mathrm{f}}$ & $0.59^{\mathrm{g}}$ & 0.02 \\
Kidney & 0.77 & 0.79 & 0.79 & 0.82 & 0.83 & 0.01 \\
\hline
\end{tabular}

Table 4: Cost implication of cassava root meal in broiler chicken diets

\begin{tabular}{lcccccc}
\hline PARAMETER & $\mathbf{T}_{\mathbf{1}}$ & $\mathbf{T}_{\mathbf{2}}$ & $\mathbf{T}_{\mathbf{3}}$ & $\mathbf{T}_{\mathbf{4}}$ & $\mathbf{T}_{\mathbf{5}}$ & $\mathbf{S E M}$ \\
\hline Price per kg feed & $110.12^{\mathrm{a}}$ & $108.92^{\mathrm{b}}$ & $106.17^{\mathrm{c}}$ & $102.22^{\mathrm{c}}$ & $98.70^{\mathrm{c}}$ & 0.59 \\
Total feed cost & $436.87^{\mathrm{a}}$ & $429.81^{\mathrm{a}}$ & $380.20^{\mathrm{b}}$ & $333.94^{\mathrm{b}}$ & $296.89^{\mathrm{d}}$ & 9.68 \\
Feed cost/gain ratio & $10.61^{\mathrm{d}}$ & $10.90^{\mathrm{d}}$ & $11.36^{\mathrm{c}}$ & $13.22^{\mathrm{c}}$ & $11.56^{\mathrm{c}}$ & 0.53 \\
Cost reduction $\%$ & - & $-2.73^{\mathrm{a}}$ & $-7.07^{\mathrm{b}}$ & $-24.60^{\mathrm{b}}$ & $-65.50^{\mathrm{d}}$ & \\
\hline
\end{tabular}

Hassan et al. (2006); Egbunike et al. (2009); Nsa et al. (2016); but contradicts the position of Adeyemi et al. (2008); Ojewola et al. (2016); Essien and Sam (2018); whose reports showed that cassava root meal can completely replace maize in broiler diets without adverse effect on utilization. The differences in the observation could be due to the fact that the later authors fortified their cassava root meal with fish meal and oil as protein and energy sources, respectively. It might also have to do with differences in variety and age of harvesting (Nsa et al., 2016). The decrease in feed intake as the level of cassava root meal increased in diets is in consonance with the findings by Ogbamgba and George (2015) and Hassan et al. (2012) who related it to the higher fiber and Hydrogen cyanide ( $\mathrm{HCN})$ contents of diets. More so, the dustiness of the feed associated with cassava root meal, low palatability, could also be the reason for reduction in feed consumption of birds fed diets with high level of cassava root meal. However, the observed results contradict earlier position of Akinmutimi (2004);
Ngiki et al. (2014); George and Sese (2012) and Igogu et al. (2013) who observed high intake of feed that contained high level of cassava root meal by birds. According to them, when anti-nutritional factors are reduced to tolerable level through efficient processing of cassava, birds eat to satisfy their nutritional needs, energy first and the other nutrients that may be low in the diet and increase in the fiber content stimulates increase consumption to meet energy and other nutrient requirements of the birds. The lower cost of feed could be attributed to the cheaper cost of cassava over maize, which is in line with the observation by Nsa et al. (2016). However, this did not reflect on the feed cost/weight gain which increased as the level of maize replacement exceeded $25 \%$ with cassava root meal. This is an indication of poor utilization of diets with a high level of cassava root meal by broiler chickens. The result is in agreement with the report of Ojewola et al. (2016); Nsa et al. (2016) and Zanu et al. (2017). However, it is in disagreement with the results obtained by Uchegbu et al. (2011), who recorded a 
relatively higher price of bird fed $45 \%$ cassava root meal. The significant higher values of liver for birds with high level of cassava root meal in their diets is probably a response to the effect of a toxic/antinutritional factors in the diets contributed by the cassava root meal.

\section{Conclusion and recommendation}

Cassava root meal replaced maize up to $25 \%$ without adverse effect on the growth parameters such as daily weight gain, daily feed intake and feed conversion ratio. Beyond 25\%, weight was depressed showing that the cassava root meal was poorly utilized. Liver weight of finisher broilers were increased as the level of inclusion of the cassava root meal increased while the cost of broiler finisher diets decreased as the level of cassava root meal increased in the diets.

It could be recommended that better processing method be employed if cassava root meal should be used in broiler finisher diet beyond $25 \%$ level.

\section{References}

Adeyemi, O. A., Eruvbetine, D., Oguntona, T., Dipeolu, M. and Agunbiade, J. 2008. Feeding broiler chicken with diets containing whole cassava root meal fermented with rumen filtrate. International Journal of Agriculture. 5(8)143140.

Agbor - Ebge and Mbome, C. 2006. Effects of processing techniques in reducing cyanogen level during the production of some Cameroonian cassava foods. Journal of food composition 19:354-363.

Akinmutimi, A. H. 2004. Evaluation of sword bean (canavalia gladiate) as an alternative feed resource for broiler chickens. Ph.D Dissertation. Michael Okpara University of
Agriculture, Umudike; Abia State, Nigeria.

Anaeto, M. and Adighibe, l. C. 2011. Cassava root meal as substitute for maize in layers ration. Brazilian Journal of Poultry Science. 13(2): 153-156.

Borin, k., Lindberg, J. E. and Ogle, R. B. 2006. Digestibility and digestive organ development in indigenous chicken and ducks fed diets with increasing inclusion of cassava leaf meal. Journal of Animal Physiology and Animal Nutrition 90 230-237.

Buitrago J. A., Gil J. L. and Ospina B. 2002. The use of cassava in animal feeding in: Cassava in the third millennium: Modern production, processing. Use and marketing systems. Columbia. Centro International de Agricultura Tropical. Pp. 526-569.

Egbunike, G.N., Agiang, E.A., Owosibo, A. O., Fatufe, A. A. 2009. Effects of protein on performance and haematology of broilers fed cassava peel based diets. Arch. Zootec. 58:655-662.

Esonu, B. O. and Udedibie, A. B. I. 2003. The effects of replacing maize with cassava meal on the performance of weaner rabbit fed diets containing cassava root, peel and seviate. Tropical Journal of Animal Science, Volume 9(1)81-87.

Essien, C. A. and Sam, I. M. 2018. Performance, carcass and organ weight characteristics of finisher broilers fed pro-vitamin A (UMUCASS 36) cassava meal. Journal of Biology and Agricultural healthcare.8:4.

Garcia, M. and Dale, N. 1999. Cassava root meal for poultry. Journal ofApplied Poultry Research. 8:132137. 
George, G. G. and Sese, B. T. 2012. The effects of whole cassava meal on broiler carcass weight and the optimal inclusion rate in broiler production. Journal of Advances in Agriculture, Sciences and Engineering Research. 2(6)184186.

Hassan, A. M., Tamburawa, M. S. Alponsus, C. and Yusuf, J. H. 2012. Studies on growth, organs weight and haematological parameters of broiler chicken fed graded level of sun dried cassava root meal. Journal of pure and Applied Sciences. 5(1)98-102.

Igogu, R. U., Udeh, F. V. and Ukeh, P. C. 2013. An assessment of the effects of feeding graded level of cassava peel meal supplemented with enzyme on finisher broiler performance. International Journal of Science and Research. 4(8)1036-1039.

Longe, O. G. and Oluyemi, J. A. 1977. Comparative use of cassava, maize and guinea corn as the major dietary source of carbohydrates for chicks. Journal of Advanced Agricultural Sciences in Africa. 4:47-52.

Munyaka, G. O., Alponsus, C. and Yusulf, J. H. 2015. Impact of combined B-glucanase and Xylanase on growth performance, nutrient utilization and gut microbiata in broiler chickens fed corn or wheat based diets. Poultry Science Journal. 95(3)528-540.

Ngiki, Y. U., Igwebuike, J. U. and Morrupa, S. M. 2014. Effects of replacing maize with cassava root meal mixture on the performance of broiler chickens. International Journal of Science and Technology. 3(6)352-362.

Nsa, E. E., Wogar, G. S. I. and Akpan, I. A. 2016. Comparative evaluation of composite cassava root meal, palm oil and crayfish waste mixture as substitute for maize in broiler chicken diets. American Journal of Experimental Agriculture. 11(4)17.

Nuss, E. and Tanumihardijo, S. A. 2010. Maize: A paramount stable crop in the context of global nutrition. Food Science and Food Safety. 9:417436.

Obikaonu, H. O. and Udedibie, A. B. I. 2006. Comparative evaluation of sun-dried and ensiled cassava peel meals as substitute for maize in broiler starter diets. International Journal of Agriculture and Rural Development. 7:52-55.

Ogbamgba, K. O. and Geoarge, S. O. 2015. Effects of processed cassava tuber meal (Garri) on performance and serum metabolites of broilers. International Journal of Science and Research. 4(3)34-45.

Ogbamgha, K. O. and George, O. S. 2012. Effects of cowpea, melon, soybean and cassava in rabbit performance. New Clues in Science 2(12)90-96.

Ojewola, G. S., Ebele, E. A. and Olojede, O. 2016. Biologic and economic performance of broiler chicken fed cassava root meal as substitute for maize. Journal of Agriculture and Vertinary Science, 9(10)10-15.

Oruwari, B. M., Sese, B. T. and Mgbere, O. O. 1995. The effects of whole palm kernel on broiler performance and production cost. International Journal of Animal Science. 10:115120.

Sarkiyayi, S. and Agar, T. M. 2010. Comparative analysis on the nutritional and anti-nutritional contents of the sweet and bitter cassava varieties. Advance Journal 
of Food Science and Technology. 2(6)328-334.

Tyner, T. and Taheripour, B. 2007. Policy option for integrated energy and agricultural markets. Review of Agricultural economics. 30(3)387396.

Uchegbu, M. C., Ogbuewu, L, P., Obimara, S. O. and Obua, B. E. 2011. Effects of replacement of maize with cassava root meal fortified with palm oil on performance of starter broilers. Online Journal of Animal and Feed Research. 1(5)171-175.
Zanu, H. K., Azameti, M. K. and Azare, D. 2017. Effects of dietry inclusion of cassava root flour in broiler diets on growth performance, carcass characteristics and haematological parameters. International Journal of Livestock production, 8(3)28-32.

Received: $16^{\text {th }}$ July, 2019

Accepted: $19^{\text {th }}$ December, 2019 